$10^{\text {th }}$ International Kimberlite Conference, Bangalore - 2012

10IKC-238

\title{
JERICHO ECLOGITE FORMATION REVEALED BY DIAMOND INCLUSIONS: OCEANIC ORIGIN WITHOUT CRUSTAL SIGNATURE?
}

\author{
K.A. Smart, T. Chacko, T. Stachel, S. Tappe, K. Muehlenbachs, R.B. Ickert and R.A. Stern \\ Department of Earth and Atmospheric Sciences, University of Alberta, Edmonton, Canada T6G2E3
}

\begin{abstract}
INTRODUCTION
The composition of the cratonic mantle is largely derived from the study of mantle xenoliths, which are known to be susceptible to modification by migrating melts and/or fluids (e.g. Harte 1987; Simon et al., 2003). In contrast, diamonds and their inclusions are more resistant to secondary processes, such that diamond inclusions (DIs) may be more reliable recorders of the coupled evolution of cratonic mantle and the overlying crust (Ireland et al., 1994). Geochemical data extracted from DIs and mantle xenoliths have prompted debate on the origin of the cratonic mantle, particularly on the long-standing issue of whether it formed by low- or high-pressure processes (e.g. Pearson and Wittig, 2008). In particular, the chemical composition and isotopic character of many eclogitic DIs and eclogite xenoliths have been widely interpreted as indicative of a low-pressure origin as oceanic crust (e.g. Jacob 2004), which was subsequently subducted to great depth and incorporated into the cratonic mantle (e.g. Jacob et al., 1994; Aulbach et al., 2002, Tappe et al., 2011).
\end{abstract}

Strong evidence for subduction of oceanic lithosphere to great depths beneath cratons is derived from the geochemical and isotopic signatures of numerous mantle eclogite xenoliths, eclogitic DIs and eclogitic diamonds. These signatures include minerals with positive $\mathrm{Eu}$ and $\mathrm{Sr}$ anomalies, interpreted as evidence of plagioclase accumulation during protolith crystallization (e.g. Barth et al., 2001). Furthermore, oxygen isotope compositions distinct from the mantle average and overlapping the ranges observed in ophiolites (Alt and Teagle 2000) and seawateraltered oceanic crust (Muehlenbachs and Clayton, 1972) point to a shallow origin as part of the oceanic crust. Finally, some eclogitic diamonds have very ${ }^{13} \mathrm{C}$-depleted carbon isotope compositions $\left(\delta^{13} \mathrm{C}<-20 \%\right)$ that are similar to the negative $\delta^{13} \mathrm{C}$ values observed in organic sedimentary carbon, consistent with diamond formation from subducted crustal components (e.g. Tappert et al., 2005).
However, this apparent clear-cut interpretation is complicated by eclogites with ambiguous 'crustal' signatures (Barth et al., 2002; Schmickler et al., 2004) that also are not compatible with a strictly 'mantle' origin (e.g. Smyth et al., 1989) and demand an alternative explanation. Moreover, the geochemical information derived from eclogites and their diamonds often appears to indicate both 'crustal' and 'mantle' origins, promoting the idea that diamond is a secondary metasomatic mineral (e.g. Cartigny et al., 2004), whose origin is decoupled from that of its hosted DIs and/or host eclogite. Here we report geochemical and isotopic data for diamonds, diamond inclusions and the host high- $\mathrm{MgO}$ eclogite xenoliths from the Jericho kimberlite of the Slave craton in Canada.

\section{RESULTS}

The garnet and clinopyroxene diamond inclusions (DIs) have markedly different compositions than their host eclogite counterparts. Garnet DIs in particular have much lower $\mathrm{Mg}$-numbers (54 vs. 82$)$ and $\mathrm{Cr}_{2} \mathrm{O}_{3}$ contents $(0.1$ vs. $0.6 \mathrm{wt} \%$ ), and classify as Group B compared to the Group A host eclogite garnets (Fig. 1a). The clinopyroxene DIs also have lower Mg-numbers (78-81 vs. 93) and slightly higher $\mathrm{Na}_{2} \mathrm{O}$ contents (2.3 vs. 1.8 wt. $\%$ ) than their host eclogite counterparts (Fig. 1b). Garnet DIs have fractionated chondrite-normalized HREE patterns $\left(\mathrm{Lu}_{\mathrm{N}} / \mathrm{Gd}_{\mathrm{N}}\right.$ $\sim 3-5)$ and clinopyroxene are LREE-enriched $\left(\mathrm{La}_{\mathrm{N}} / \mathrm{Sm}_{\mathrm{N}} \sim 1.4\right)$. Both minerals show small negative $\mathrm{Eu}$ anomalies $\left(\mathrm{Eu} / \mathrm{Eu}^{*}=0.7-0.9\right)$ and clinopyroxene DIs also show negative $\mathrm{Sr}$ anomalies. The garnet and clinopyroxene DIs have overall similar REE patterns to those minerals in the host eclogite, but in detail, host clinopyroxene is far more enriched in LREEs than the DIs ( $\mathrm{Ce}_{\mathrm{N}} \sim 92$ vs. 35) and Eu anomalies are not observed in the host minerals (Fig. 2). Oxygen isotope compositions of garnet DIs, and garnet and clinopyroxene from the host eclogite have $\delta^{18} \mathrm{O}$ values of $5.2-6.0 \%$, which overlap the average mantle value of $\sim 5.5 \%$. 

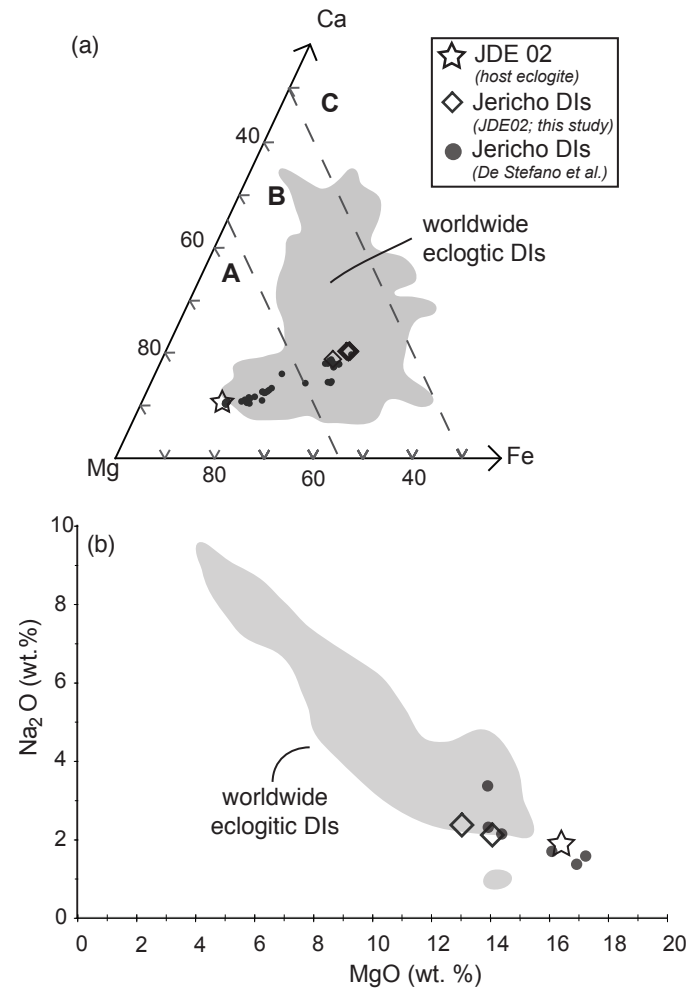

Fig. 1(a). Ca-Mg-Fe composition of the Jericho garnet DIs. Shown for comparison is the composition of garnet from the host eclogite JDE02, as well as other garnet diamond inclusions extracted from xenocrystic diamonds from Jericho (De Stefano et al. 2009). (b) Composition of Jericho clinopyroxene DIs with similar comparisons as in (a).

\section{DISCUSSION}

The Jericho DIs and host eclogite minerals do not display any of the key "crustal" signatures, but instead appear to show evidence for a mantle cumulate origin given the fractionated HREE patterns and mantle-like $\delta^{18} \mathrm{O}$ values (cf., Barth et al. 2002). In contrast, the encapsulating diamonds have extremely low $\delta^{13} \mathrm{C}$ values of $-40 \%$, similar to the $\delta^{13} \mathrm{C}$ values down to $-41 \%$ reported for other Jericho diamonds by De Stefano et al. (2009). These carbon isotope compositions are much more depleted in ${ }^{13} \mathrm{C}$ than the average mantle $\delta^{13} \mathrm{C}$ value of $-5 \%$. Smart et al. (2011) argued that these extremely ${ }^{13} \mathrm{C}$-depleted carbon isotope compositions cannot be generated from 'average' mantle carbon through fractional crystallization and/or source fluid/melt fractionation processes. Rather, they must have been inherited from an unusual carbon source. Carbonate and organic sediments have average $\delta^{13} \mathrm{C}$ values of approximately $0 \%$ and $-25 \%$, respectively (Schidlowski, 2001), and thus cannot represent the carbon source for diamond formation. However, at ca. 2.7 and 2.0 Ga, the carbon isotope record for organic sediments displays negative excursions in $\delta^{13} \mathrm{C}$ values down to $-60 \%$. Therefore, as putative subduction events are thought to have affected the Slave craton at approximately these times, the diamonds may have been formed from fluids/melts mobilized from subducted Neoarchean or Paleoproterozoic organic sediments (Smart et al., 2011). Thus, the Jericho high-MgO eclogites and their DIs appear to be genetically decoupled from one another, that is, diamond formation is unrelated to eclogite formation, in line with the conclusion that diamond is a metasomatic, secondary mineral (e.g. Cartigny et al., 2004).

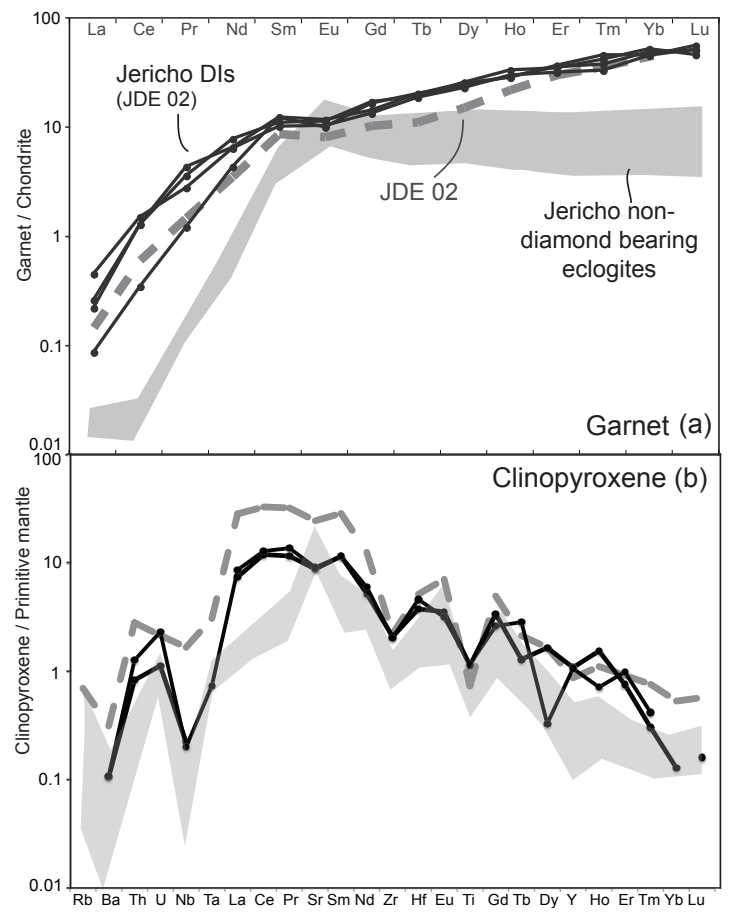

Fig. 2(a). Chondrite-normalized rare-earth element profiles for the Jericho garnet DIs. Garnets from host eclogite JDE02 and other Jericho nondiamond eclogites for comparison. (b) Primitive-mantle normalized multielement plot for Jericho clinopyroxene DIs with the same comparisons as in (a).

Further insight into the origin of the Jericho high-MgO eclogites and their DIs may be gained from the presence of small negative $\mathrm{Sr}$ and $\mathrm{Eu}$ anomalies in the DIs. Generally, positive $\mathrm{Eu}$ and $\mathrm{Sr}$ anomalies in eclogitic materials are taken as evidence of a low-pressure origin involving plagioclase accumulation in a basaltic precursor magma (e.g. Aulbach et al., 2002; Barth et al., 2001). Negative anomalies, as observed here, may also indicate eclogite protolith formation at low pressures, albeit in a scenario where either plagioclase was removed from the precursor melt that later formed the eclogite protolith (i.e., fractional crystallization), or an originally plagioclase-bearing protolith underwent partial melting during which plagioclase was fully exhausted. While the negative Eu and 
Sr anomalies may indicate protolith formation at low pressures, they alone do not confirm protolith formation as upper oceanic crust (Jacob, 2004). The mantle-like oxygen isotope compositions of the DIs and host eclogites do not provide further constraints on the protolith, as they do not show evidence of seawater alteration. However, seemingly 'mantle-like' $\delta^{18} \mathrm{O}$ values do not preclude an origin as oceanic crust, because the protolith may have formed in the upper portion of the sheeted dike section where the temperature of seawater-rock interaction is such that there is little shift in the oxygen isotope composition of basalts. Alternatively, the protolith may have formed in the lower reaches of the oceanic lithosphere below the possible influence of seawater (e.g. Hart et al., 1999; Schmickler et al., 2004).

The equilibration temperatures calculated for the host eclogite $\left(900^{\circ} \mathrm{C}\right.$ at $\left.5 \mathrm{GPa}\right)$, and presence of diamond indicate final eclogite equilibration within the diamond stability field in the Jericho cratonic mantle, such that after initial low-pressure crystallization, the eclogite protoliths were transported to depth. We favor subduction as the most likely transfer mechanism of the eclogite protolith for several reasons. There is strong geophysical evidence for modification of the Slave cratonic mantle by subduction during the Paleoproterozoic (e.g. Cook et al., 1999). Additionally, mantle xenoliths from the Jericho kimberlite have both geochemical compositions that suggest both lowpressure origins and and radiometric ages that correspond to the timing of known subduction events (e.g. De Stefano et al., 2009; Wittig et al., 2008; Schmidberger et al., 2005). Therefore, we propose that the Jericho high-MgO eclogites crystallized as part of the oceanic lithosphere that was subducted beneath the Jericho kimberlite.

The fractionated HREE patterns observed in both the garnet DIs and calculated DI whole-rock compositions suggest that garnet accumulation occurred during protolith crystallization. Both garnet and minor plagioclase, along with clinopyroxene (and potentially amphibole, orthopyroxene or quartz) crystallize from basaltic liquids at pressures of ca. 1.5-2.0 GPa (e.g Rapp and Watson 1995). Hence, such uppermost mantle plagioclase-garnetclinopyroxene "cumulates" may well represent a viable protolith for the Jericho high-MgO eclogites.

The hypothesized mineral assemblage of the cumulate protolith dictates that crystallization must have occurred at depths of $50-70 \mathrm{~km}$. Although such depths significantly exceed the thickness of modern oceanic crust, Jericho eclogite formation occurred during Paleoproterozoic subduction that was associated with the Wopmay orogeny (Schmidberger et al., 2005) and therefore oceanic crust was likely much thicker at this time (Bickle 1986). The maximum thickness of oceanic crust at the ArcheanProterozoic boundary has been modeled to be $25-35 \mathrm{~km}$ (Herzberg, 2010). At these depths, formation of cumulates with the pertinent mineral assemblage would be impossible, but favourable conditions may have been met if crystallization occurred in veins within the bottom part of thick oceanic lithosphere (Foley et al., 2001). Formation of the Jericho high-MgO eclogites as cumulate veins within the oceanic mantle lithosphere is envisaged as being similar to the occurrence of pyroxenitic veins within alpine peridotite massifs (e.g. Pearson et al., 1993; Becker 1996).

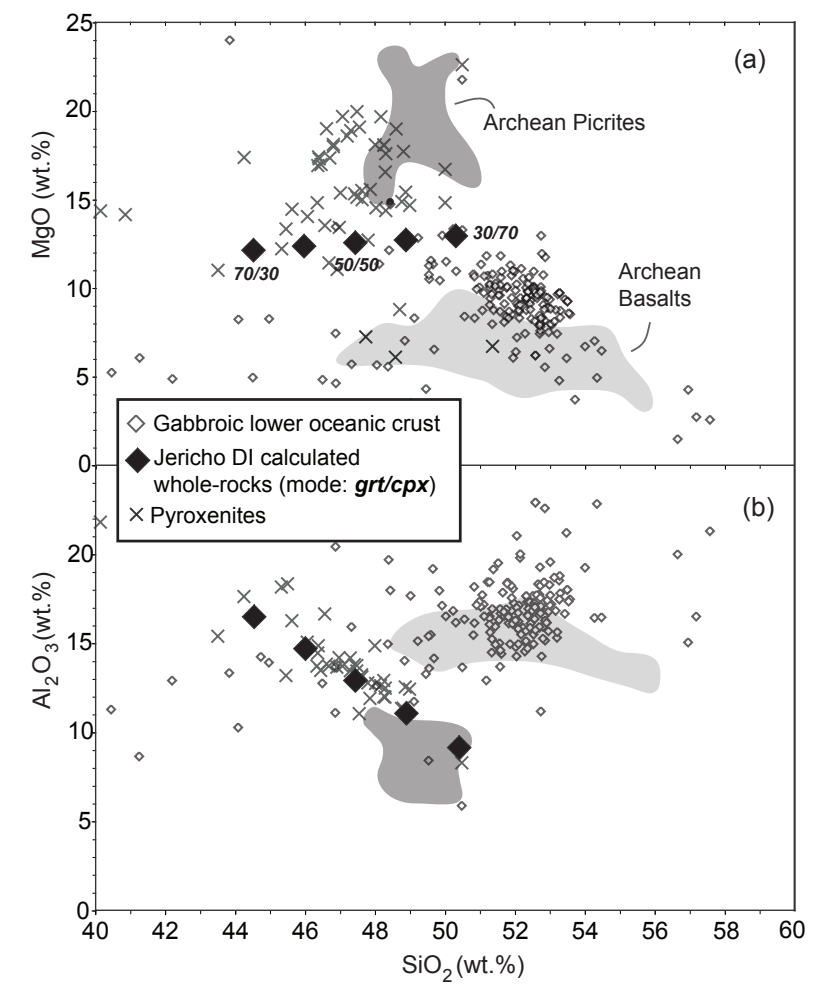

Fig. 3. Comparison of calculated Jericho DI whole-rocks to pyroxenite veins from peridotite massifs (Becker, 1996; Pearson et al., 1993), modern oceanic gabbros (Hart et al., 1999), and Archean basalts and picrites (Polat et al., 2008). The DI whole-rock compositions were calculated for modes from $70 \%-30 \%$ to $30 \%-70 \%$ garnet-clinopyroxene, respectively.

The clear compositional disparity between the Jericho DIs and their host high-MgO eclogite indicates that secondary processes affected the eclogites subsequent to diamond formation. Secondary Mg-enrichment of the host eclogite is also supported by studies of the trace element and isotopic composition of high-MgO eclogites (Smart et al., 2009) and secondary Mg-enriched minerals in other Jericho eclogites (De Stefano et al., 2009). Therefore, the DIs will be used to constrain the composition of the protolith. Calculation of whole-rock compositions from DIs is associated with large 


\section{$10^{\text {th }}$ International Kimberlite Conference, Bangalore - 2012}

uncertainties given the unknown modal mineral proportions (e.g. Aulbach et al., 2002). Therefore, we calculate wholerock compositions for a range of possible garnetclinopyroxene modes in order to constrain the protolith of the Jericho DIs (Fig. 3). In Figure 3 we compare the range of calculated DI whole-rock compositions with pyroxenites from continental peridotite massifs. The pyroxenites and whole-rock DIs (for the 60-40/40-60 garnet-clinopyroxene modal range) have overlapping $\mathrm{Al}_{2} \mathrm{O}_{3}, \mathrm{SiO}_{2}, \mathrm{CaO}$ and $\mathrm{Na}_{2} \mathrm{O}$ (latter two not shown), but in general the pyroxenites have higher Mg-numbers. The higher $\mathrm{Mg}$ contents of the pyroxenites could simply be due to equilibration of the pyroxenite veins with the surrounding peridotite.

In conclusion, based on lack of a clear 'subduction signature' and the mantle-like $\delta^{18} \mathrm{O}$ values of the Jericho diamond inclusions, as well as petrological modelling, we propose that the high- $\mathrm{MgO}$ diamond eclogites originated as cumulates from basaltic melts at pressures between ca. 1.5$2.0 \mathrm{GPa}$. These pressures of origin correspond to the bottom parts of oceanic lithosphere during the Paleoproterozoic or earlier. Subduction stacking of oceanic lithosphere (e.g. Pearson and Wittig, 2008, Tappe et al., 2011) to form cratonic mantle brought the Jericho eclogites into the diamond stability field. Diamond formation occurred at a later stage from fluids/melts that were mobilized from subducted organic matter with extreme $\delta^{13} \mathrm{C}$ values of $40 \%$. This organic carbon was derived from either the same piece of oceanic lithosphere that contained the Jericho eclogites, or alternatively from any other deeply subducted slice of stacked oceanic lithosphere beneath the Slave craton. As we envisage the protolith of Jericho high-MgO eclogites to have formed as veins within the bottom part of oceanic lithosphere (e.g. Foley et al. 2001), the sedimentderived diamond-forming fluids/melts could have been sourced from the shallow reaches of another imbricated slab, following the geometry of the subduction-stacking model. An ultimate origin of the of the Jericho eclogites and their diamonds from different domains and levels within oceanic lithosphere may also help to explain their decoupled "mantle" and "crustal" signatures, respectively. It therefore appears that the subduction-stacking mechanism provides the simplest means to reconcile the apparently conflicting geochemical signatures of the Jericho eclogites and their diamonds

\section{REFERENCES}

Alt J.C. and Teagle D.A.H. (2000) Hydrothermal alteration and fluid fluxes in ophiolites and oceanic crust. In: Dilek, Y., E. Moores, and D. Elthon and A. Nicolas, eds., Geol. Soc. Am. Spec. Paper 349, Ophiolites and Oceanic Crust: New Insights from Field Studies and Ocean Drilling Program, 273-282.

Aulbach S., Stachel T., Viljoen K.S., Brey G.P., and Harris J.W. (2002) Eclogitic and websteritic diamond sources beneath the Limpopo belt - is slab-melting the link? Contrib. Mineral. Petrol. 143, 53-70.
Barth M.G. Rudnick R.L., Horn I., McDonough W.F., Spicuzza M.J., Valley J.W. and Haggerty S.E. (2002) Geochemistry of xenolithic eclogites from West Africa. Part 2: Origins of high MgO eclogites. Geochim. Cosmochim. Acta 66, 4325-4434.

Becker H. (1996) Crustal trace element and isotopic signatures in garnet pyroxenites from garnet peridotite massifs from Lower Austria. J. Petrol. 37, 785-810.

Bickle M.J. (1986) Implications of melting for stabilization of the lithosphere and heat loss in the Archean. Earth Planet. Sci. Lett. 80, 314-324.

Cartigny P., Stachel T., Harris J.W. and Javoy M. (2004) Constraining diamond metasomatic growth using $\mathrm{C}$ - and $\mathrm{N}$-stable isotopes: examples from Namibia. Lithos 77, 359-373.

Cook F.A., van der Velden A.J., Hall K.W. and Roberts B.J. (1999) Frozen subduction in Canada's Northwest Territories: Lithoprobe deep lithospheric reflection profiling of the western Canadian Shield. Tectonics 18, 1-24.

De Stefano A., Kopylova M.G., Cartigny P. and Afanasiev V. (2009) Diamonds and eclogites of the Jericho kimberlite (Northern Canada). Contrib. Mineral. Petrol. 158, 295-315.

Foley S.F., Petibon C.M., Jenner G.A. and Kjarsgaard B.A. ( 2001) High $\mathrm{U} / \mathrm{Th}$ partitioning by clinopyroxene from alkali silicate and carbonatite metasomatism: an origin for $\mathrm{Th} / \mathrm{U}$ disequilibrium in mantle melts. Terra Nova 13,104-109.

Hart S.R., Blusztajn J., Dick H.J.B., Meyer P.S. and Muehlenbachs K. (1999) The fingerprint of seawater circulation in a 500-meter section of oceanic crust gabbros. Geochim. Cosmochim. Acta 63, 4059-4080.

Harte B. (1987) Metasomatic events recorded in mantle xenoliths: An overview. In: Nixon, P. H. (Ed.), Mantle Xenoliths. John Wiley and Sons, UK, pp. 625-640.

Herzberg C., Condie K. and Korenaga J. (2010) Thermal history of the Earth and its petrological expression. Earth Planet. Sci. Lett. 292, 79-88.

Ireland T.R., Rudnick R.L. and Spetsius Z. (1994) Trace elements in diamond inclusions from eclogites reveal link to Archean granites. Earth Planet. Sci. Lett. 128, 199-213.

Jacob D.E. (2004) Nature and origin of eclogite xenoliths from kimberlites. Lithos 77, 295-316.

Jacob D., Jagoutz E., Lowry D., Mattey D. and Kudrjavtseva G. (1994) Diamondiferous Eclogites from Siberia - Remnants of Archean Oceanic-Crust. Geochim. Cosmochim. Acta 58, 5191-5207.

Muehlenbachs K., and Clayton R. N. (1972) Oxygen isotope geochemistry of submarine greenstones. Can. J. Earth Sci. 9, 471478.

Pearson D.G. and Wittig N. (2008) Formation of Archaean continental lithosphere and its diamonds: the root of the problem. J. Geol. Soci. London 165, 895-914.

Pearson D.G., Davies G.R. and Nixon P.H. (1993) Geochemical constraints on the petrogenesis of diamond facies pyroxenites from the Beni Bousera peridotite massif, North Morocco. J. Petrol 34, 125-172.

Polat A., Frei R., Appel P.W.U., Dilek Y., Fryer B., Ordonez J.C. and Yang Z. (2008) The origin and compositions of Mesoarchean oceanic crust: Evidence from the 3075 Ma Ivisaartoq grenstone belt, SW Greenland. Lithos 100, 293-321.

Rapp R.P. and Watson B. (1995) Dehydration melting of metabasalt at 8-32 kbar: Implications for continental growth and crust-mantle recycling. Journal of Petrology 36, 891-931.

Schidlowski M. (2001) Carbon isotope as biogeochemical recorders of life over 3.8 Ga of Earth history: evolution of a concept. PreCam. Res. 106, 117-134.

Schmickler B., Jacob D.E. and Foley S.F. (2004) Eclogite xenoliths from the Kuruman kimberlites, South Africa: geochemical fingerprinting of deep subduction and cumulate processes. Lithos 75, 173-207. 
Schmidberger S.S., Heaman L.M., Simonetti A., Creaser R.A. and Cookenboo H.O. (2005) Formation of Paleoproterozoic eclogitic mantle, Slave Province (Canada): Insights from in-situ Hf and U-Pb isotopic analyses of mantle zircons. Earth Planet. Sci. Lett. 240, 621-633.

Simon N.S.C., Irvine G.J. Davies G.R., Pearson D.G. and Carlson R.W. (2003) The origin of garnet and clinopyroxene in "depleted" Kaapvaal peridotites. Lithos 71, 289-322.

Smart K.A., Heaman L.M., Chacko T., Simonetti A., Kopylova M., Mah D. and Daniels D. (2009a) The origin of high-MgO diamond eclogites from the Jericho kimberlite, Canada. Earth Planet. Sci. Lett. 284, 527-537.

Smart K.A., Chacko T., Stachel T., Muehlenbachs K., Stern R.A. and Heaman L.M. (2011) Diamond growth from oxidized carbon sources beneath the Northern Slave Craton, Canada: A $\delta^{13} \mathrm{C}-\mathrm{N}$ study of eclogite-hosted diamonds from the Jericho kimberlite. Geochim. Cosmochim. Acta 75, 6027-6027.

Smyth J.R., Caporuscio F.A. and McCormick T. (1989) Mantle eclogites: evidence of igneous fractionation in the mantle. Earth Planet. Sci. Lett. 93, 133-141.

Tappe S., Smart K.A., Pearson D.G., Steenfelt A. and Simonetti A. (2011) Craton formation in Late Archean subduction zones revealed by first Greenland eclogites. Geology 39, 1103-1106.

Tappert R., Stachel T., Harris J.W., Muehlenbachs K., Ludwig T., and Brey G. (2005) Subducting oceanic crust: The source of deep diamonds. Geology 33, 565-568.

Wittig N., Pearson D.G., Webb M., Ottley C.J., Irvine G.J., Kopylova M., Jensen S.M. and Nowell G. (2008) Origin of cratonic lithospheric mantle roots: A geochemical study of peridotites from the North Atlantic Craton, West Greenland. Earth Planet. Sci. Lett. 274, 2433. 